\title{
A Case of Benign Vascular Tumor of Tympanic Membrane
}

\author{
Young Ju Kim ${ }^{1}$, Ah-young Kwon ${ }^{2}$, and Hyoung-Mi Kim ${ }^{1}$ \\ ${ }^{1}$ Departments of Otorhinolaryngology-Head and Neck Surgery, ${ }^{2}$ Pathology, CHA Bundang Medical Center, CHA University, \\ Seongnam, Korea
}

\section{고막에 발생한 양성 혈관성 종괴 1예}

김영주 $^{1} \cdot$ 권아영 $^{2} \cdot$ 김형미 ${ }^{1}$

차의과학대학교 분당차병원 이비인후과-두경부외과학교실, ${ }^{1}$ 병리학교실 ${ }^{2}$

\author{
Received August 30, 2014 \\ Revised October 29,2014 \\ Accepted October 31, 2014 \\ Address for correspondence \\ Hyoung-Mi Kim, MD \\ Department of Otorhinolaryngology- \\ Head and Neck Surgery, \\ CHA Bundang Medical Center, \\ CHA University, 59 Yatap-ro, \\ Bundang-gu, Seongnam \\ 463-712, Korea \\ Tel $+82-31-780-5340$ \\ Fax $+82-31-780-5347$ \\ E-mail hyoungkim@cha.ac.kr
}

\begin{abstract}
Benign vascular lesions are rarely found on the tympanic membrane. To date, only 21 cases restricted to tympanic membrane and/or external auditory canal have been reported, and all cases are hemangioma. We recently experienced a case of a vascular lesion arising from the atrophic tympanic membrane, which did not respond to initial $\mathrm{CO}_{2}$ laser therapy. Subsequent surgical excision of the vascular lesion was successfully performed. The clinical manifestations and management of benign vascular lesion of tympanic membrane are discussed with a review of literature. Korean J Otorhinolaryngol-Head Neck Surg 2015;58(4):290-3
\end{abstract}

Key Words Hemangioma - Tympanic membrane - Vascular malformation.

\section{서 론}

중이를 침범하지 않고 고막 또는 외이도에 국한되어 나타나 는 양성 혈관성 병변은 매우 드물어 국내 3 예 ${ }^{1-3}$ 를 포함하여 현 재까지 21예 정도가 보고된 바가 있다. 보고된 증례 모두 혈관 종으로 진단되었고, 고막 또는 외이도에 단독으로 나타나거나 고막과 외이도에 걸쳐진 병변의 형태로 발현되었으며 전례에서 수술적 절제술을 시행하였다. 양성 혈관성 병변은 크게 혈관내 피세포의 증식으로 능동적으로 성장하는 혈관 종양(vascular tumor)과 내피세포의 증식 없이 시간 경과에 따라 단순히 확장 되기만 하는 혈관 기형(vascular malformation)으로 분류할 수 있다.) 혈관종은 혈관 종양의 대표적인 질환으로 두경부 영 역에서는 비교적 흔하게 나타나며 빠르게 증식과 관해를 반 복하는 혈관세포에 의해 형성되어 조직학적으로 해면상, 모 세상 및 혼합형으로 분류된다. 저자들은 고막에 국한된 혈관 성 병변을 이내 접근법에 의한 제거술을 통해 좋은 결과를 경험하였기에 문헌고찰과 함께 보고하는 바이다.

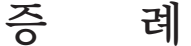

52세 남자 환자가 1 개월 전부터 발생한 좌측 이충만감 및 간헐적 두통을 주소로 2009년 6월 내원하였다. 과거력상 30 여 년 전 좌측 귀의 중이염으로 치료를 받았던 병력 외에 외 상 등의 특이사항은 없었으며, 이충만감 외에 이명, 이통, 이 루, 현훈 및 안면마비 등의 소견은 보이지 않았다. 내원시 시 행한 이학적 검사상 좌측 고막의 고실경화반(tympanosclerotic plaque) 및 전반적인 반흔성 천공 소견이 보였으며, 고막 상부 에 돌출된 비교적 경계가 명확한 적색의 혈관성 병변이 관찰 되었다. 최근 발생한 외상이나 염증의 병력은 없었으나 초진 시 혈종을 의심하였고 순음청력검사 시행결과 양측 귀의 각 각 저주파 및 고주파에 국한된 감각신경성 난청 소견 보였으 며, 좌측 귀의 $10 \mathrm{~dB}$ 이내의 경도의 전음성 난청 소견을 보 였다(Fig. 1). 항생제 등의 보존적 치료 후, 환자의 증상은 호전 되었으나 이내시경 검사상 지속된 병변 소견으로 2개월 뒤 국 소마취하에 $\mathrm{CO}_{2}$ 레이저(Sharplan 30C, Tel Aviv, Israel) 치료 


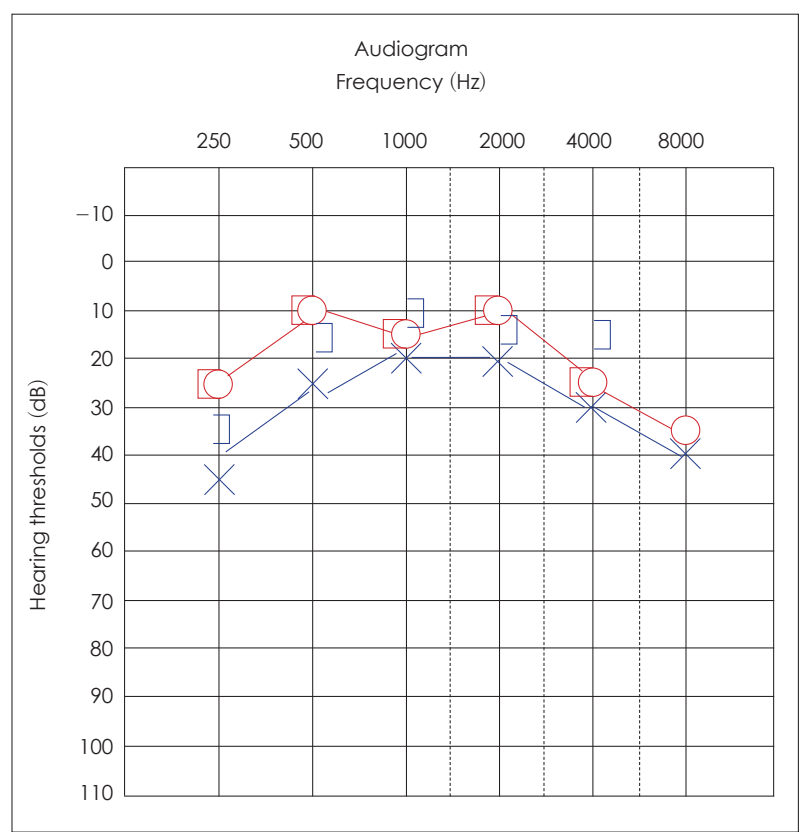

Fig. 1. Pure tone audiogram shows sensorineural hearing loss at low and high frequency in both ear and mild conductive hearing loss in left ear.
를 시행하였으나 이후 환자는 추적 관찰되지 못하였다(follow up loss). 4년여가 지난 2013년 5월, 2주 전부터 머리 움직임 에 의해 심해지는 어지럼을 주소로 환자는 다시 내원하였다. 이학적 검사상 이전과 동일한 양상의 좌측 고막상부에 국한 된 적색의 혈관성 병변이 관찰되었으며, 우측 고막은 특이소 견을 보이지 않았다(Fig. 2). 환자는 새로이 동반된 어지럼 외 에 특이 증상 호소하지 않았다. 순음청력검사상 2009년과 비교했을 때 전음성 난청의 소견은 뚜렷하지 않았으며, 어지럼 에 대해 시행한 전정기능검사에서 우측 수평반고리관의 이석 증 소견을 보여 이석정복술을 시행한 후 어지럼은 호전되었다. 측두골 전산화단층촬영에서 좌측 고막에 이소골과 접해 있 는 연부조직 음영의 종물이 보였으며 중이 및 내이로의 침범 은 없었다(Fig. 3). 4년 전과 유사한 고막의 혈관성 병변에 대 해 임상적으로 고막에 국한된 혈관종을 의심하였고, 내원 2 개월 뒤 국소마취하에 $\mathrm{CO}_{2}$ 레이저 치료를 다시 시행하였다. 레이저 치료시 병변을 통해 선홍색의 혈액을 확인할 수 있었 다. 술 후 7일째 외래에서 시행한 이내시경 검사상 레이저 치 료에 전혀 반응하지 않은 종괴를 확인하였고, 국소마취하에
Fig. 2. Otoscopic finding, reddish colored mass of the left tympanic membrane $(A)$ and right tympanic membrane (B).

Fig. 3. Temporal bone CT scans demonstrate a soft tissue density lesion (arrow) just lateral to the tympanic membrane. Axial $(\mathrm{A})$ and coronal view (B).
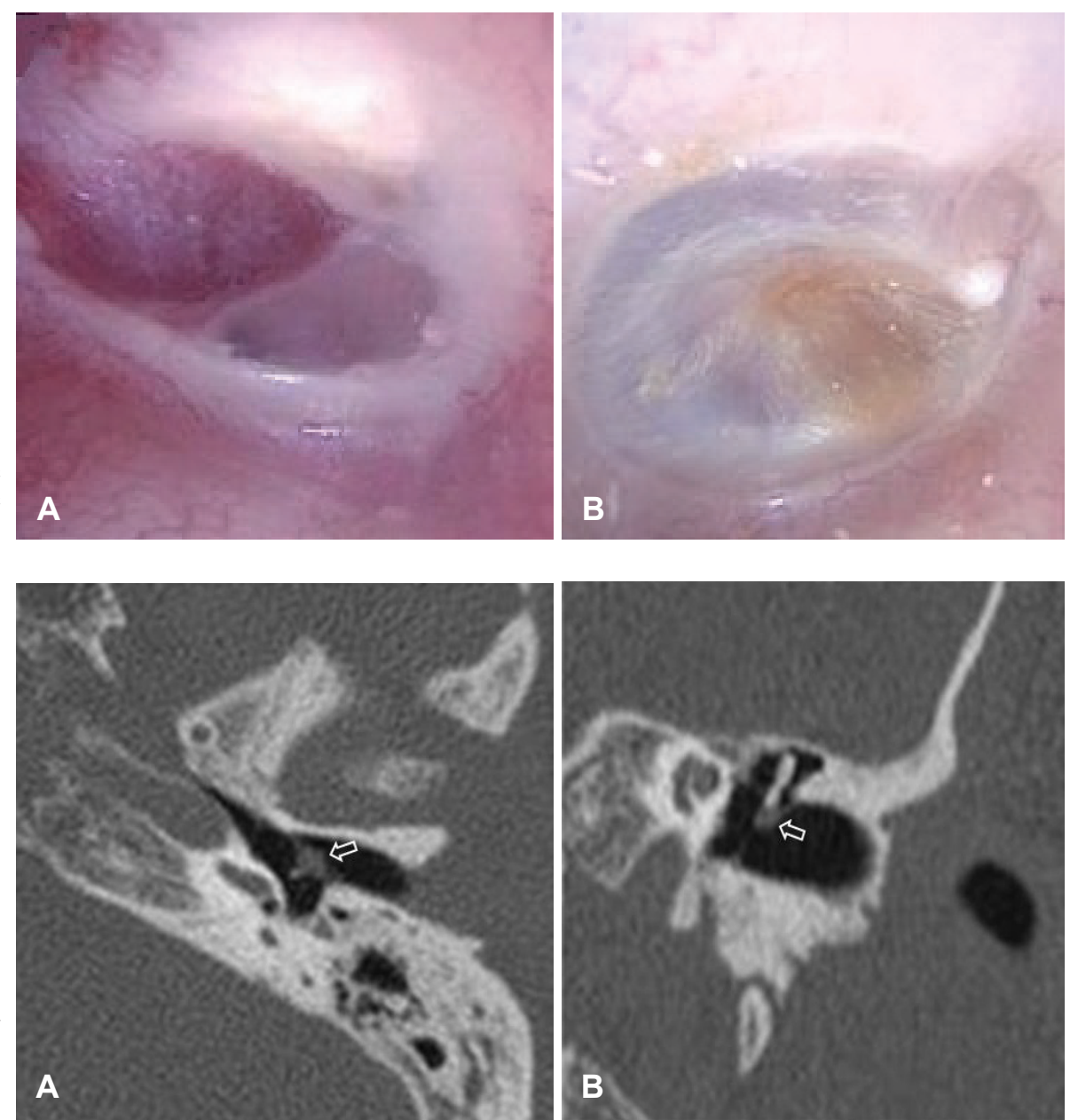


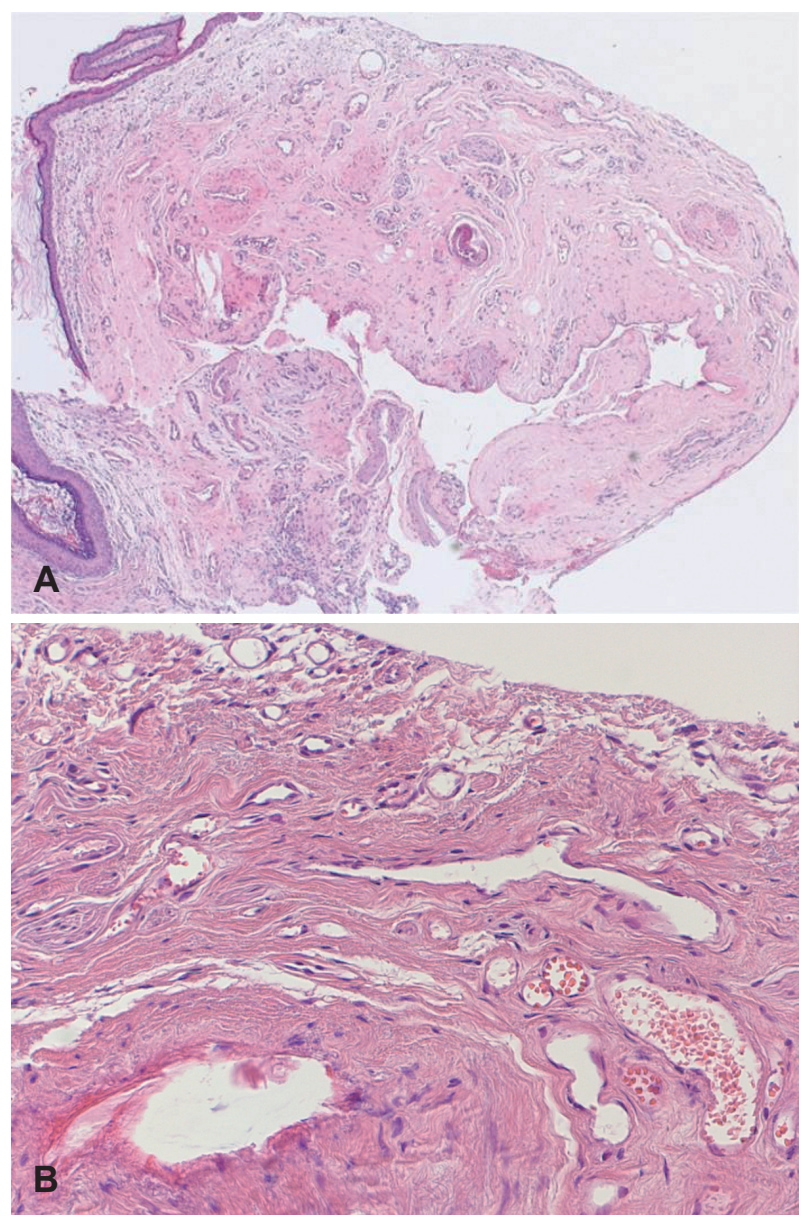

Fig. 4. Pathologic photograph showing proliferation of variablesized vessels with stromal fibrosis (H-E stain, $\times 40)(A)$. The lesion reveals variable-sized, dilated, and blood-filled vessels with haphazard pattern. The vascular walls are focally thickened by fibrosis $(H-E$ stain, $\times 200)(B)$.

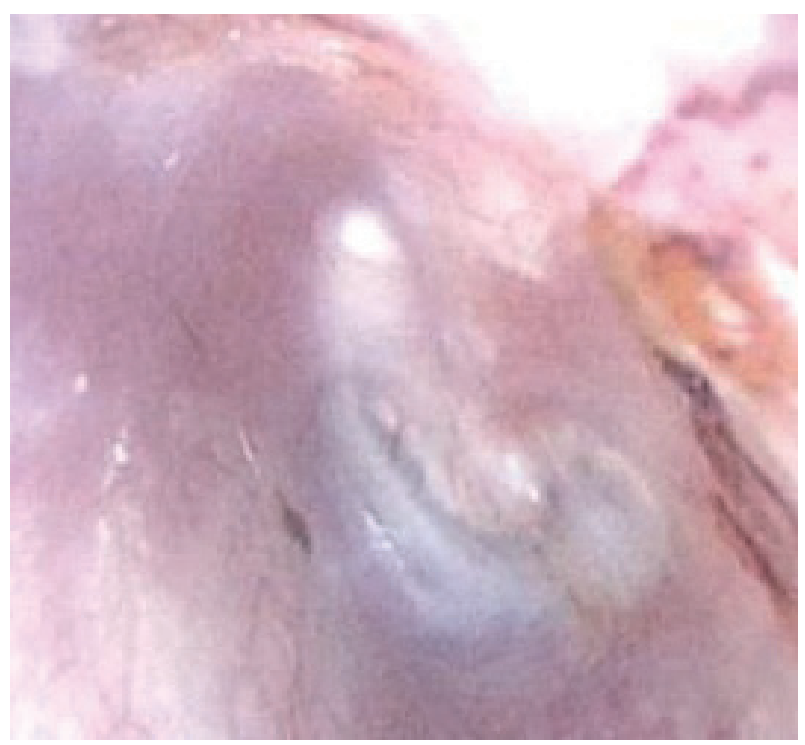

Fig. 5. Post-operative otoscopic finding of left tympanic membrane after 1 year follow-up.
이내 접근법을 통하여 종괴제거술 및 고막성형술을 시행하 였다. 반흔성 천공의 소견이 있는 고막임을 감안해 고막과 종 괴를 따로 분리하지 않고 고막을 포함하여 en-bloc으로 제거 하였고, 고막의 결손 부위는 연골막을 이용하여 재건하였다. 제거된 종괴의 크기는 $0.4 \times 0.3 \times 0.2 \mathrm{~cm}$ 였고, 광학현미경 소견 상 섬유화를 동반한 혈관 증식성 병변의 소견을 보였고(Fig. 4), 염증세포는 관찰되지 않았다. 환자는 현재 술 후 1 년째로 재 발의 징후는 없으며(Fig. 5), 정기적인 추적 관찰 중이다.

\section{고 찰}

양성 혈관성 종양 중 가장 대표적인 질환은 혈관종이며 영 유아기 선천성 두경부 종양에서 가장 흔한 질환으로 알려져 있고, 출생 1 세까지 대부분 발생되고, 발생 후 6 개월까지 급 격히 자라다가 18 개월 이후에는 서서히 퇴화를 시작하여 5 세경에는 $50 \%, 7$ 세경에는 $70 \%, 12$ 세까지는 대부분 자연관 해가 된다. ${ }^{5)}$ 따라서 성인에서의 발생 빈도는 소아에 비해 굉 장히 낮으며 특히 외이도 및 고막에서 발생하는 경우는 극히 드물다. 1972년 Freedman 등에에 의해 처음 보고된 이후 국 내에서 보고된 총 3 예 $\left.{ }^{1-3}\right)$ 를 포함하여 전세계적으로도 21예 정도만 보고된 바 있다(Table 1). 병리조직학적으로 크게 해 면상, 모세상 및 혼합형으로 분류되며 성인에서는 상대적으 로 모세혈관종에 비해 자연적 퇴화 비율이 적은 해면상 혈관 종이 많은 것으로 알려져 있다. ${ }^{7)}$ 현재까지 보고된 21예 중 해 면상 혈관종이 15 예(71.4\%)로 가장 많았고, 모세혈관종이 5예, 혼합형이 1예 ${ }^{8}$ 였다. 이 중 고막에 국한된 경우가 7예(Table 1), 외 이도에만 발생한 경우가 7예, 고막과 외이도를 모두 침범한 경우가 7예가 있었으며, 고막에 국한되어 나타난 경우는 3예 가 모세혈관종, 4 예가 해면상 혈관종으로 진단되었다. 남자가 15 예, 여자가 6예로 50대의 중년 남자의 비율이 높았다. 고막 및 외이도 혈관종의 임상 증상은 환측 청력감소, 이명, 이루, 이통 및 현훈 등이 다양하게 나타났으며 무증상으로 우연히 발견된 경우도 전체 21예 중 6예로 많은 편이었다. 이학적 검 사상 주로 외이도 및 고막의 후방에서 적색의 종물로 관찰되 며 청력 감소의 정도는 혈관종의 위치나 크기에 따라 다양하 고 중이 내로의 침범된 경우는 보고된 바 없었다. ${ }^{7}$

일반적인 두경부 혈관종의 치료로는 절제술, 소작술, 방사선 치료, 스테로이드 주사, 레이저 치료 등이 이용되고 있다. ${ }^{5}$ 레이 저 치료의 원리는 병변의 크기와 깊이, 위치에 따른 적절한 레이저를 선택하여 산화 헤모글로빈과 같은 작용을 통해 혈 관손상을 유발하는 것인데, 재발될 가능성이 있고, 특히 해 면상 혈관종의 경우 큰 혈관과 연결되어 있는 경우가 있어 수술로 완전히 절제하지 않으면 치료가 되지 않는 경우가 있 
Table 1. Reported cases of hemangioma of the tympanic membrane

\begin{tabular}{|c|c|c|c|c|c|}
\hline Author & Sex/age & Location & Symptom & Treatment & Pathology \\
\hline Balkany, et al. ${ }^{12)}$ & $F / 63$ & $\mathrm{TM}$ & None & Excision+myringoplasty & Capillary \\
\hline Andrade, et al. ${ }^{13)}$ & $M / 59$ & TM & None & Excision+myringoplasty & Cavernous \\
\hline Bijelic, et al. ${ }^{14)}$ & $\mathrm{F} / 78$ & TM & None & Excision+myringoplasty & Cavernous \\
\hline Hiraumi, et al. ${ }^{15)}$ & $M / 51$ & TM & Otorrhea+HL & Excision & Capillary \\
\hline Spector, et al. ${ }^{10)}$ & $\mathrm{F} / 59$ & TM & $\mathrm{HL}+$ tinnitus & Excision & Capillary \\
\hline Jang, et al. ${ }^{3)}$ & $M / 49$ & TM & $\mathrm{HL}+$ tinnitus & Excision+myringoplasty & Cavernous \\
\hline Mevio, et al. ${ }^{7}$ & M/55 & TM & $\mathrm{HL}+$ tinnitus & Excision & Cavernous \\
\hline
\end{tabular}

$\mathrm{TM}$ : tympanic membrane, $\mathrm{HL}$ : hearing loss

다.9) 따라서 안면 등에 발생하여 미용적으로 문제가 되지 않 는 경우에는 수술적 절제술이 안전할 것으로 여겨진다. 현재 까지 보고된 고막이나 외이도에 생긴 혈관종의 경우 절제술 이 가장 좋은 치료 효과를 보이고 있으며 ${ }^{7)}$ 절제술 후 재발을 한 경우는 1990년 Jackson 등이이 보고한 1예가 있었지만, 현 재까지 고막 및 외이도 혈관종이 악성으로 전환된 보고는 없 어 조기에 진단하여 이내 접근법을 통해 절제해주는 것이 가 장 좋은 치료방법으로 생각된다. ${ }^{10)}$ 다만 수술 전 컴퓨터단층촬 영 등을 통해 중이 내 침범여부를 확인할 필요는 있다.

본 증례의 경우 첫 번째 내원 당시 이충만감, 두통 등의 증 상이 동반되었고, 이후 몇 년 뒤 이석증으로 인한 어지럼으 로 내원하여 우연히 발견된 경우로 좌측 귀의 혈관성 병변에 의한 증상은 무증상이었으며 병변의 크기가 크지 않아 청력 에 미치는 영향 또한 미미하였다. 첫 번째 국소 레이저를 이 용한 치료 몇 년 후 동일한 병변이 지속된 점을 고려할 때 임 상적으로 혈관종이 강력하게 의심되었다. 비록 추적 관찰되 지 못하였지만 이전에 레이저를 이용한 치료를 시도했던 점 을 고려하여 $\mathrm{CO}_{2}$ 레이저를 이용한 국소 치료를 다시 한 번 시 도하였으나 레이저를 이용한 치료효과는 기대할 수 없었다. 최종 병리 결과는 혈관종의 가능성을 배제할 수 없는 섬유 화를 동반한 혈관 증식성 병변으로 보고되었지만, 현재까지 보고된 증례들이 모두 혈관종으로 최종 진단된 점과 두 번의 레이저 치료를 거치면서 혈관종 내부에 섬유화가 진행되었을 가능성1을 고려하였을 때, 본 증례 또한 고막의 혈관종일 가 능성이 높다고 하겠다. 또한 병리소견에서 혈관들의 크기가 다양하게 확장되어 있고 불규칙적인 배열을 보이며 일부에서 는 두꺼운 혈관벽을 보인다는 점에서 해면상 혈관종의 가능 성이 높은 것으로 확인되었다. 본 증례 및 현재까지 보고된 증례를 고려하였을 때 혈관성 병변이 고막 또는 외이도에 국
한하여 발생하는 경우에는 수술적 절제술 통한 병변의 제거 가 가장 효과적인 치료방법이 될 것으로 생각된다.

\section{REFERENCES}

1) Cho KH, Kim KH, Lee KS, Yang HS. A case of capillary hemangioma in the external auditory canal. Korean J Otolaryngol-Head Neck Surg 2001;44(9):993-6.

2) Song SY, Choi YH, Bai CH. Cavernous hemangioma of the external auditory canal: a case report. Korean J Otolaryngol-Head Neck Surg 2006;49(8):845-8.

3) Jang CH, Choi HS, Hong YS, Cho YB. Cavernous hemangioma of the tympanic membrane. Clin Exp Otorhinolaryngol 2011;4(2):109-11.

4) Enjolras O, Wassef M, Chapot R. Color atlas of vascular tumors and vascular malformations. 1st ed. New York: Cambridge University Press; 2007.

5) Zheng JW, Zhang L, Zhou Q, Mai HM, Wang YA, Fan XD, et al. A practical guide to treatment of infantile hemangiomas of the head and neck. Int J Clin Exp Med 2013;6(10):851-60.

6) Freedman SI, Barton S, Goodhill V. Cavernous angiomas of the tympanic membrane. Arch Otolaryngol 1972;96(2):158-60.

7) Mevio E, Cazzaniga M, Mullace M, Paolotti D. Hemangioma of the tympanic membrane: a case and a review of the literature. Case Rep Otolaryngol 2012;2012:402630.

8) Jackson CG, Levine SC, McKennan KX. Recurrent hemangioma of the external auditory canal. Am J Otol 1990;11(2):117-8.

9) Al Buainian H, Verhaeghe E, Dierckxsens L, Naeyaert JM. Early treatment of hemangiomas with lasers. A review. Dermatology 2003; 206(4):370-3.

10) Spector ME, Adams ME, Arts HA. Capillary hemangioma of the tympanic membrane. Am J Otolaryngol 2011;32(6):615-6.

11) Marsili M, Cockerell CJ, Lyde CB. Hemangioma-associated rhinophyma. Report of a case with successful treatment using carbon dioxide laser surgery. J Dermatol Surg Oncol 1993;19(3):206-12.

12) Balkany TJ, Meyers AD, Wong ML. Capillary hemangioma of the tympanic membrane. Arch Otolaryngol 1978;104(5):296-7.

13) Andrade JM, Gehris CW Jr, Breitenecker R. Cavernous hemangioma of the tympanic membrane. A case report. Am J Otol 1983;4(3):198-9.

14) Bijelic L, Wei JL, McDonald TJ. Hemangioma of the tympanic membrane. Otolaryngol Head Neck Surg 2001;125(3):272-3.

15) Hiraumi $H$, Miura $M$, Hirose T. Capillary hemangioma of the tympanic membrane. Am J Otolaryngol 2005;26(5):351-2. 